\title{
Escolarizar para moralizar: discursos sobre a educabilidade da criança pobre (1820-1850)
}

\author{
Maria Cristina Soares de Gouvêa \\ Mônica Yumi Jinzenji
}

Universidade Federal de Minas Gerais, Faculdade de Educação

Muito tem sido produzido nos últimos anos, no Brasil, sobre história da infância, quer no âmbito da história, quer no da história da educação. Em levantamento realizado sobre o tema, Irma Rizzini indica que, na década de 1980, foram desenvolvidos 38 estudos, entre artigos, dissertações e teses; já na década de 1990, são registradas 160 produções (in Rizzini \& Fonseca, 2001). Tais trabalhos têm possibilitado conferir visibilidade e legibilidade aos processos sociais de formação das diferentes infâncias brasileiras, nos diversos espaços educativos e momentos históricos.

A pluralidade de estudos tem indicado, por um lado, um tratamento da história da infância brasileira que busca compreendê-la a partir de sua pertinência social, etária, étnica e de gênero, categorias que vêm norteando tais produções. Por outro lado, vem sendo dado destaque tanto à produção e circulação de práticas de intervenção junto às crianças brasileiras, quanto à produção, circulação e apropriação de saberes sobre a infância. ${ }^{1}$ Por fim,

${ }^{1}$ A respeito do levantamento da produção da história da infância no Brasil, ver Kuhlmann Jr. (1998); Rizzini e Fonseca (2001); e Gouvêa (2003). vêm sendo investigados períodos históricos tradicionalmente pouco contemplados, como o século XIX, o que vem ocorrendo mais sistematicamente nos últimos cinco anos.

No interior desse escopo, buscamos aqui analisar os discursos sobre a infância, em circulação no contexto educacional escolar mineiro da primeira metade do século XIX. Tem-se em vista contribuir para um alargamento da produção da história da educação da infância no Brasil, contemplando um período histórico ainda pouco analisado, destacando a singularidade da primeira metade do século XIX, como também enfatizar a especificidade dos discursos acerca da infância pobre e sua educabilidade, inserido num projeto de escolarização dos extratos considerados inferiores da população.

A utilização de múltiplas fontes possibilitou-nos o acesso a discursos de diversas naturezas, contribuindo para a compreensão da complexidade que marcava o cenário educacional da sociedade mineira na primeira metade do século XIX. Assim, tivemos como fonte privilegiada um manual didático-pedagógico de origem francesa, intitulado Curso normal para pro- 
fessores de primeiras letras ou direcções relativas á educação physica, moral e intellectual nas escolas primarias, escrito pelo barão Joseph-Marie De Gérando (1839); o periódico O Universal, impresso na capital mineira de Ouro Preto, e que circulou no período de 1825 a 1842; a legislação educacional mineira; os relatórios dos presidentes da província de Minas Gerais; mapas trimestrais de freqüência dos alunos das escolas elementares, preenchidos pelos professores para recebimento do salário; ofícios, requerimentos e portarias referentes à instrução pública mineira; relatórios dos delegados de ensino.

O entrecruzamento das fontes constitui estratégia fundamental, na pesquisa histórica, para contemplar a complexidade da construção da vida social, a polifonia de discursos e práticas produzidos pelos distintos atores sociais, a partir de sua inserção. Porém, cabe considerar a especificidade de cada produção discursiva, tendo em vista as condições e hierarquias entre os distintos espaços de produção, circulação e apropriação dos discursos sociais, que informam sua natureza.

No caso desta investigação, a leitura do manual foi priorizada, tendo em vista seu caráter discursivo de veículo difusor de saberes e práticas sobre a educação e seus sujeitos, a serem apreendidos pelos professores que fundamentariam o exercício de seu ofício. O manual continha as conferências dadas por De Gérando nos cursos de formação de professores da Escola Normal francesa, e sua aquisição foi requerida pelo governo da província mineira como recurso para a formação do professorado. ${ }^{2}$ Constitui, portanto, importante fonte para a apreensão dos saberes historicamente legitimados de ordenação das práticas pedagógicas. A utilização do periódico $O$ Universal tem em vista o fato de ter sido um veículo importante e difusor do ideário liberal no interior da província mineira,

${ }^{2}$ Infelizmente, não temos dados referentes à recepção de tal manual na província mineira, embora tenha-se buscado sinais de sua circulação. Para estudo do manual, ver os trabalhos de Bastos (1999), Jinzenji (2002), Rosa (2001). tendo publicado sistematicamente estudos sobre a educação, considerada estratégia fundamental de normatização social. Os jornais, ao longo do século XIX, constituíram instrumento fundamental de formação política da população e de circulação de idéias, permitindo-nos ter acesso à dinâmica dos embates em torno da escolarização da população brasileira. ${ }^{3}$

As demais fontes trabalhadas referem-se a documentos que buscavam ordenar e normatizar o funcionamento da escola, em seu caráter institucional. Os espaços de produção e circulação conferem visibilidade não apenas aos discursos, mas às práticas de implementação e funcionamento de um incipiente "sistema escolar". Cabe destacar a singularidade de cada discurso, produzido por autores diferenciados, hierarquicamente situados (professores, delegados literários encarregados do acompanhamento das escolas, presidentes de província), produtores de saberes e práticas com alcance diverso. ${ }^{4}$

Concebemos que as fontes utilizadas para a realização desta investigação nos fornecem um dos possíveis olhares sobre nosso objeto de estudo; os recortes do real produzidos por parte da elite política dirigente e demais atores sociais envolvidos com o processo de escolarização da população mineira. Compreendemos que as práticas voltadas para a intervenção na sociedade por meio da educação eram impregnadas pelas representações sobre essa mesma população e, consequientemente, sobre a infância e sua educabilidade. Nesse sentido, essas representações condicionavam as práticas, ao mesmo tempo em que eram condicionadas por elas, numa relação dialética e indissociável entre representações e práticas sociais.

${ }^{3}$ A respeito da imprensa mineira no período indicado, ver Silva (2002), bem como os trabalhos de Jinzenji (2002), Faria Filho e Souza (1998), que contemplam a análise dos discursos sobre educação nesse periódico.

${ }^{4}$ Sobre as fontes contempladas, ver os trabalhos de Veiga (2004) e Gouvêa (2004). 


\section{A produção da escola como espaço de aprendizagens e socialização}

As primeiras décadas do século XIX no Brasil foram caracterizadas por profundas mudanças sociais e políticas, nas quais o Estado nascente, após a Independência, buscava marcar sua presença nas diferentes províncias por meio de um governo central que ordenasse a construção de um projeto de nação. Tal governo, com a afirmação da monarquia, corporificada na figura de d. Pedro II, coroado aos cinco anos de idade, deu início ao período da regência, inicialmente de tendência liberal. Buscava-se construir uma ordem que, de um lado, tirava poder dos municípios, e de outro criava, pelo Ato Adicional de 1834, as assembléias provinciais, representantes do poder central. Porém, as revoltas seriam freqüentes em várias dessas províncias, revoltas marcadas pela disputa das elites e da população local pelo poder e pela afirmação de sua autonomia, o que demonstrava a fragilidade do governo imperial. Se algumas revoltas se transformaram em guerra popular, como no caso da Cabanagem no Pará, a Sabinada na Bahia, e a Revolta Praieira pernambucana, em outras as elites mantiveram o controle, como na Revolta Liberal mineira e paulista de 1842 (Carvalho, 1998).

A ebulição política e a fragilidade do poder central na construção de condições de governabilidade levariam à busca de instrumentos de normalização social e de conformação de uma ordem pública. No âmbito do poder central, isto se deu em torno do Partido Conservador, que iria assumir a hegemonia política a partir de 1841 , criando uma justiça e polícia controladas pelo governo imperial.

Assim é que, no caso da Revolta Liberal mineira e paulista, segundo Luis Felipe Alencastro (1997), "havia nas duas províncias a crença de que o governo centralista do Rio, dominado por conservadores, tornara-se fortemente ditador, ao desencadear uma violenta perseguição contra as Câmaras, arrogando-se atribuições policiais e judiciárias pertencentes às municipalidades" (p. 18). O controle dessa revolta por parte do governo teria como consequiência um refluxo do poder político das elites mineiras no cenário nacional, identificadas com o ideário liberal. Porém, foi apenas na segunda metade do século XIX que o Estado nacional conseguiria afirmar-se como poder central, pondo fim às revoltas locais, sob hegemonia do Partido Conservador, o que Ilmar Mattos (1994) definiu como Tempo Saquarema.

Toda essa tensão social e política deixaria suas marcas no processo de institucionalização da escola elementar, ao longo do período. No contexto europeu, esta foi progressivamente assumida como responsabilidade do Estado e como estratégia de coesão nacional, frente ao perigo representado pela insurgência das camadas pobres. Pela extensão da instrução elementar ao grosso da população, buscava-se construir uma adesão à ordem pública e ao poder constituído nos novos Estados-nação, condição de afirmação da ordem civilizada. ${ }^{5}$

No Brasil, o processo de institucionalização da escola elementar foi marcado pela precariedade. A instrução assumia centralidade nas discussões políticas e na formulação de estratégias de formação da população, aos moldes europeus. Momento de intensos debates acerca da necessidade de difundir as luzes às camadas inferiores da sociedade, nas décadas iniciais do governo imperial registram-se esforços em organizar a instrução pública, voltada principalmente para essas camadas da população. O grande contingente populacional marcado pela pobreza era considerado uma ameaça à tranqüilidade pública, sendo-lhe atribuída responsabilidade sobre a criminalidade e a instabilidade dos governos. Em consonância com os ideais iluministas, acreditava-se na instrução como meio de civilizar essa população, possibilitando a sua submissão às leis e à almejada ordem, contribuindo para o fortalecimento do Estado imperial.

${ }^{5}$ Cabe destacar que, mesmo nos países centro-europeus, foi apenas a partir da segunda metade do século XIX que a escola se afirmou como espaço educador da população, com a difusão das leis de obrigatoriedade escolar. 
Na província mineira, o povoamento no decorrer do período colonial deu-se a partir da exploração aurífera, sendo a população formada, genericamente, por aventureiros em busca de fortuna, e por um grande contingente de escravos, necessários para o trabalho de mineração. Com a decadência desta, no século XIX, a população mineira mostrava-se, com um grande número de desocupados. Os dados econômicos demonstram que a economia mineira se deslocou para a agricultura, que, segundo Alencastro (1997), ampliou suas atividades também na pecuária e laticínio, fornecendo alimentos para o Rio de Janeiro. Porém, tais atividades não conseguiam absorver a mão-de-obra livre, levando à construção de uma imagem da população mineira do período associada à vagabundagem ou ao latrocínio, que se faziam presentes nas perigosas estradas da região. No dizer de Duarte (1995),

[...] a emergência de uma população desclassificada cuja distribuição irregular pelo território povoava as mentes e escritos de cronistas, autoridades governamentais e demais componentes da boa sociedade - demandava providências e soluções. A vil canalha constituía um universo que não podia ser enquadrado nos limites do governo ou do trabalho, constituindo um mundo de desordem. (p. 42)

A maior parte da população mineira era, portanto, constituída por sujeitos das camadas inferiores. Se verificarmos a conformação étnica dessa população em fins do século XVIII, constataremos que aproximadamente $22,09 \%$ correspondiam aos brancos, $15,67 \%$ aos pardos, e 52,22\% eram negros. ${ }^{6}$ Tendo aproximadamente um terço da população formada por escravos e uma minoria de brancos, havia uma grande massa de homens livres e pobres, sendo a maioria constituída de mestiços e negros forros e fugidos.

Em meio à centralidade assumida pela necessidade de instrução da grande massa de homens livres e pobres, a escolarização aparecia como estratégia

${ }^{6}$ Ver Souza (1986). governamental de controle social, de civilização do povo nos moldes europeus. Assim é que a formulação de aparatos legais ${ }^{7}$ que sustentassem as iniciativas de extensão da escola à população livre foi seguida da criação de escolas elementares e do investimento na formação de professores para provê-las, por meio da criação de escolas normais. A influência do modelo educacional centro-europeu era visível, através da importação dos métodos de ensino lá utilizados, como o método mútuo, ${ }^{8} \mathrm{o}$ envio de professores à França para que aprendessem tais métodos, assim como a introdução de um manual didático-pedagógico francês, o Curso normal para professores de primeiras letras (De Gérando, 1839), considerado o primeiro do gênero a ser introduzido no Brasil, utilizado como suporte para a formação dos normalistas.

Trata-se, portanto, de um período marcado por discussões e práticas que apontavam para a necessidade de profundas transformações no campo educacional, o que contribuiria para o fortalecimento do Estado imperial recém-fundado. Escolarizar a população pobre e livre, dispersa por todo o território nacional, implicaria a produção e afirmação da escola como instituição privilegiada de formação das novas gerações. Para tanto, além da elaboração de leis e da criação de espaços oficiais que caracterizariam essa nova estrutura formativa, passou-se também a produzir novas "referências sociais tendo a escola, ou a forma escolar de socialização e transmissão de conhecimentos, como eixo articulador de seus sentidos e significados." (Faria Filho, s.d.). Instituir a escola como instância formadora privilegiada significava

${ }^{7}$ A exemplo da primeira lei imperial referente à instrução, de 15 de outubro de 1827 , e a lei mineira $n^{\circ} 13$, de 28 de março de 1835, que organiza o ensino e a profissão docente na província.

${ }^{8}$ Conhecido também como método monitorial ou lancasteriano, desenvolvido na Inglaterra em fins do século XVIII e difundido pela Europa e continente americano no início do século XIX. O método previa o ensino de centenas de alunos ao mesmo tempo, em amplos espaços, contando com apenas um professor e a ajuda de monitores. Ver Bastos e Faria Filho (1999). 
combater outras formas de transmissão e produção culturais, o que implicaria a reorganização ou redefinição de papéis de outras instituições diretamente ligadas à educação, sendo uma delas a família. Porém, no dizer de José Murilo de Carvalho, "a educação primária não foi utilizada como instrumento eficaz de socialização política [...] a preocupação da elite imperial com o problema da identidade nacional resumiu-se em tentar socializar e convencer setores divergentes da própria elite" (1998, p. 240-241).

Embora no discurso das elites a escolarização da população livre fosse apresentada como necessidade imperiosa de consolidação da ordem pública, o Estado central transferiu às províncias a responsabilidade pela instrução elementar, segundo o ato adicional de 1834, assumindo, todavia, a educação superior. Porém, à descentralização de funções do Estado, como a educação, correspondeu a centralização da distribuição das rendas públicas. Segundo Franco (1997), "especialmente a partir de 1840 foi-se consolidando um governo centralizador, sentido esse que aparece distintamente na discriminação das rendas públicas em nada favorável à província e ao município, em particular a este" (p. 121).

Verifica-se que as províncias, ao longo de todo o período imperial, tiveram enorme dificuldade na institucionalização da escola elementar. No dizer de Faria Filho (2001),

[...] quando relacionamos os investimentos na instrução com os orçamentos provinciais, eles não eram assim tão parcos como se imagina ou descreve. No entanto, entre a grande importância atribuída à instrução e a operacionalização de fato de uma política que a concretizasse interpunham-se elementos de várias ordens, entre eles sem dúvida a baixíssima capacidade de arrecadação da província e a luta dos grupos dominantes pelo investimento em outros níveis de instrução que não o primário, como o funcionamento de colégios secundários particulares. (p. 96)

Trataremos a seguir dos desdobramentos resultantes da reivindicação de que a escola assumisse um papel formativo da população, tendo como eixo nor- teador as representações da infância e de sua educabilidade. Educar a população por meio de sua escolarização significava trazer para o centro das discussões das políticas educacionais questões relacionadas à identidade do aluno. Esse sujeito era definido por um recorte geracional - a idade da meninice -, período considerado ideal para a realização da aprendizagem escolar. Assim é que o pertencimento geracional seria um dos eixos em torno dos quais foi construída a identidade do aluno.

\section{A identidade do aluno: pertencimento geracional, racial e de gênero}

O artigo 12 da lei provincial $n^{\circ} 13$, de 1835 , delimitava a idade escolar como o período compreendido entre os 8 e 12 anos no caso do menino, quando os pais deveriam encaminhar os filhos à instrução primária, sob pena de multa. No caso da menina, a legislação não estabelecia a instrução elementar como obrigatória.

Embora a legislação buscasse definir os contornos etários da categoria aluno, há de destacar-se que, na análise dos mapas trimestrais de freqüência, era corriqueira a presença de crianças de 5 ou 6 anos, sendo raramente registrados alunos de mais de 15 anos. Provavelmente os sujeitos dessa faixa etária estavam inseridos em outros espaços sociais relacionados ao trabalho, marcando uma vivência relacionada ao universo adulto. ${ }^{9}$ No relatório de um delegado de ensino, ao levantar-se o número de possíveis alunos do município, percebe-se uma visão diferenciada da legislação, no que se refere à faixa etária a ser escolarizada:

[...] em que me pede informações dos habitantes livres que compreende este arraial e seus subúrbios, ao que respondo que no arraial e suas vizinhanças contém 557 al-

${ }^{9}$ É importante registrar que também os meninos e meninas com idade situada entre os 8 e 14 anos desenvolviam atividades de trabalho, tanto doméstico, quanto externo remunerado, fator que muito contribuiu para a não adesão das famílias à escola ao longo desse período. 
mas livres e entre estas 135 meninos de ambos os sexos de 5 a 12 anos de idade quase todos sem saberem ler e todos estes podem vir á escola. (Minas Gerais, 1839b)

A presença corriqueira de alunos com idade inferior à prevista na legislação que definia a obrigatoriedade escolar é indicativa de que, ante a dificuldade de arregimentar um corpo de alunos na faixa etária prevista, os professores recebiam crianças menores, que ainda não estavam tão comprometidas com o trabalho. Indica também, talvez, uma concepção geracional brasileira diferenciada da européia, a qual parece ter sido a referência indicada na construção desse ordenamento jurídico. No relato dos viajantes europeus, tal questão é fonte de comentários. Luccock, em 1810, afirmava que "deve se levar em conta a idade prematura em que as pessoas novas deixam já de ser consideradas como crianças" (apud Leite, 1997, p. 28). O autor citado analisa as diferenciações internas à categoria infância a partir da observação do vestuário:

[...] tanto meninos quanto meninas vivem a trançar nus pela casa, até que atinjam cerca de 5 anos, e durante três ou quatro anos ainda, após essa idade, nada mais usam que a roupa de baixo [...] quando em raras ocasiões tem que ir a Igreja ou em visitas, vestem-nas com toda elegância rígida de uma época que já passou; não há diferença, salvo nas dimensões entre os trajes, de um rapaz que faz pouco adquiriu o garbo viril e os de seu pai, entre os de uma menina e os de sua majestosa mãe. (idem, ibidem)

Ou ainda, segundo depoimento de 1886 de Edgecumbe:

[...] no Brasil não existem crianças no sentido inglês. A menor menina usa colares e pulseiras e meninos de 8 anos fumam cigarros. Encontrei um bando de meninos voltando da escola. Um pequeno de aparentemente sete anos tirou do bolso um maço de cigarros e ofereceu a cada um. (apud Leite, 1997, p. 37)

No que se refere à identidade de gênero, a educação das meninas diferenciava-se da dos meninos pelo conteúdo e duração da escolarização, devendo também ser realizada em estabelecimentos separados. O ensino das meninas era limitado aos níveis elementares do ensino primário, acrescido de noções de ensino moral, religioso e doméstico, indicando uma formação voltada para as ocupações do lar. Segundo o presidente da província Bernardo Jacintho da Veiga, quanto à especificidade do ensino para as meninas,

[...] devem ensinar-lhes tudo quanto convem que saiba huma mulher, que tem de ser criada de si e de seu marido; por isso a sua educação deve limitar-se a saber ler, escrever e contar... (Minas Gerais, 1835-1846; Relatório de 1843)

Os dados fornecidos pelos presidentes da província a partir de seus relatórios indicam que o número de alunas correspondia, em média, a menos de $10 \%$ do número total de alunos no período, mantendo uma proporção semelhante o número de escolas destinadas a um e outro sexo. Quanto a isso, o presidente Bernardo Jacintho da Veiga afirmava que, se o número de meninos matriculados ainda era irrisório e insatisfatório, a situação das meninas era ainda pior. Segundo ele, até a regulamentação do acesso desse público ao ensino, pela lei de 15 de outubro de 1827 , a educação do bello sexo era

[...] até então circunspecto nos limites de uma educação domestica, quase sempre acanhada, e bem ou mal dirigida segundo o caracter, habitos, e modo de pensar de cada um Pai de familia: que esse tempo, digo eu, não tem sido ainda sufficiente para se formarem Professoras que por meio de concurso sejão providas em todas as Cadeiras vagas. (Minas Gerais, 1835-1846; Relatório de 1840)

$\mathrm{O}$ insuficiente número de escolas para meninas parecia não impedir, no entanto, o seu acesso às demais escolas. Conforme consta,

[...] muitas [meninas] existem matriculadas nas $\mathrm{Au}-$ las do sexo masculino, nos lugares, onde não existem próprias para o seu sexo. (Minas Gerais, 1835-1846; Relatório de 1839) 
Essa convivência dos dois sexos no interior da mesma sala de aula não se fazia sem restrições que dificultassem um maior contato entre meninos e meninas, como o uso de cortinas separando os dois grupos. ${ }^{10}$

Tendo em vista a categoria raça, há de destacarse que não havia, na legislação da província mineira, restrições à inserção na escola de crianças negras e pardas, mas os escravos eram impedidos de ser escolarizados. Nos mapas de frequiência da década de 1820, é possível identificar um retrato da composição racial de algumas salas de aula, pois os professores registravam a identidade racial dos alunos, dado que foi suprimido posteriormente. ${ }^{11}$

Rellação de meninos q actualmente frequentão a Escolla das primeiras Letras nesta Ca. Do Paracatu do $\operatorname{Pr}^{\mathrm{e}}$.

7 Antonio Jose Ferreira 8 mezes e esta lendo escrito e letra redonda, fazendo conta de Sommar e escrevendo Letra grande e he pardo.

8 Ezaquiel Maximiano, e seu Irmão Felismino Antonio Guimes ambos brancos dous mezes de escolla commigo e estão lendo escrito e Cartilha e escrevendo Letra meiam, e estudando a taboada

9 João Francisco Per a (pardo) e está em carta de nome.

10 Luis Ferreira Guim es p 1 e $1 / 2$ e esta lendo escrito, e Snnca e letra redonda e escrevendo letra de meião fazendo Conta diminuir

11 Francisco Antonio de Arruda negro a 1 e sete mezes escrevendo A.B.C. pequeno, e grande e já sabe a Taboada e esta lendo escrito

12 Domingos Alves de Sta Anna Negro 1 anno, e dous mezes esta lendo escrito, e taboada, e escreve A.B.C. Pequeno. (Minas Gerais, 1823, envelope 7)

${ }^{10}$ A respeito da escolarização feminina no século XIX na província mineira, ver Muniz (2003) e Gouvêa (2004).

${ }^{11}$ Para análise da inserção de crianças negras e pardas nas escolas elementares ao longo do período, ver Veiga (2004).
Portanto, o projeto de escolarização da infância no período assumia significações e contornos diferenciados. Tinha-se em vista não apenas a condição jurídica de sujeito livre, mas a posição social dos alunos, bem como o gênero.

\section{A educabilidade da criança}

A população à qual a instrução elementar era dirigida na província mineira era a dos estratos pobres, o que fica claro a partir dos relatos dos delegados, nos quais é freqüente a alusão às origens sociais da população escolar, destacando sua pobreza. Num relatório ao presidente da província, o delegado assim se expressa:

Constata-se matriculados e distribuidos pelas escolas 673 alunos. Maior seria o número destes em as escolas se a suma pobreza de alguns pais a ponto de não poderem ministrar á seus filhos os alimentos e vestuários nas escolas existentes nas províncias onde eles moram, não obstante o darem-lhe a instrução primária, cujas infelizes circunstâncias me tem sido provadas por alguns deles. Este inconveniente que neutraliza ao Artigo n. 12 da lei n. 13, poderá somente ser removido se a Assembléia Provincial mandar fornecer ainda que muito marcamente seja o alimento e fato absolutamente indispensavel para estes meninos infelizes, que por um semelhante motivo são condenados á uma perpetua ignorância de tudo. (Minas Gerais, 1839c)

Cabe, portanto, compreender o projeto de escolarização pretendido, tendo em vista tratar-se de um perfil específico; cabe-nos analisar como era entendida a educabilidade da criança pobre. ${ }^{12}$

A adoção do manual Curso normal para professores de primeiras letras (1839), do barão De Gérando, em diversas províncias brasileiras, diz-nos acerca das referências para a definição do perfil e dos contornos do projeto de educação escolar pretendido

\footnotetext{
${ }^{12}$ Para melhor compreender a inserção das crianças pobres
} na escola elementar do período, ver Veiga (2002). 
no Brasil, naquele período. O barão De Gérando representava uma das figuras centrais da filantropia européia da primeira metade do século XIX, defensor da extensão da escola ao grosso da população, principalmente às classes inferiores. Filósofo, autor de obras sobre pensamento e linguagem, era membro destacado da Société des Observateurs de Homme, grupo formado por homens ilustres provenientes de várias áreas do saber, que existiu do final do século XVIII ao início do século XIX. Faziam parte desse grupo os médicos Pinel, Cabanis, Itard, o filósofo Destutt de Tracy, os naturalistas Jussieu, Cuvier, Saint-Hillaire e Jaufett, secretário da sociedade. Segundo este, o objetivo do grupo era

coletar uma grande quantidade de fatos, multiplicar as observações, deixando de lado toda vã teoria, toda especulação arriscada que só serve para trazer novas trevas a um estudo já obscuro por si mesmo. (Montanari apud BanksLeite \& Galvão, 2000, p. 14)

Foi De Gérando o introdutor, nas reuniões da referida société, dos relatos de Itard acerca do processo de educação do chamado Selvagem de Aveyron, o famoso Vitor, que iria ter ampla repercussão no período e ao longo dos próximos séculos. Itard defendia a educabilidade do selvagem, dizendo que tal palavra designava os indivíduos de pouca civilização e que, na falta de um termo mais preciso que definisse melhor o caso do menino encontrado quase na ausência de contato cultural anterior, utilizaria o mesmo vocábulo.

Se ao longo dos séculos XVII e XVIII afirmouse a idéia de educabilidade da infância, os séculos XVIII e XIX iriam voltar-se para a relação educação e civilização. Trazendo os ecos de um discurso iluminista, De Gérando, Itard e outros autores buscaram discutir não a educação da criança dos meios abastados, condição à qual referiam-se os estudos anteriores de Erasmo, Locke e Rousseau. Voltava-se agora para a educabilidade dos selvagens, desde os sujeitos das camadas inferiores, advindos de um meio social que ainda não atingira os benefícios das luzes, até os sujeitos de outras culturas, ou mesmo daqueles que não tiveram contato com a cultura humana. Para esses autores, educar era civilizar.

De Gérando iria defender não apenas a viabilidade de educação das crianças das classes laboriosas, mas principalmente sua absoluta necessidade, fundamento que iria sustentar a construção de sua obra. No Curso normal, o barão De Gérando (1839) deixava clara a percepção da pluralidade da infância, ganhando absoluto destaque os originários das classes pobres. Nas suas palavras, as escolas de primeiras letras seriam freqüentadas por "indivíduos das classes inferiores da humanidade", "meninos pertencentes às condições menos abastadas", referindo-se também a "meninos desamparados" e "indigentes". Além desses adjetivos, que apontam de forma mais direta a condição social à qual pertenciam esses alunos, outros, como "meninos de tenra idade", "tenros anos", "tenros discípulos", "idade infantil", agregam-lhe noções relacionadas à sua maturação biológica e desenvolvimento das faculdades mentais. A esses meninos de tenra idade eram atribuídas algumas características que, entendidas como sendo-lhes imanentes, buscavam configurar uma espécie de natureza infantil, tais como a ingenuidade, pureza, inocência e fragilidade. Essas características eram tratadas como desejáveis, devendo ser ressignificadas, constituindo a base da ação da educação escolar.

A pureza e a ingenuidade não eram os únicos elementos que caracterizavam a infância. Percebemos no discurso do barão De Gérando outras características que denotam a percepção da diferença entre crianças e adultos, por exemplo, quando falava de uma "inteligência infantil", entendida como ainda pouco desenvolvida; ou às "disposições da infância", segundo as quais as crianças seriam "inconstantes, volúveis, cubiçosos de novidade". Esse reconhecimento da especificidade da criança, no entanto, diferenciava-se da concepção de Rousseau, principalmente no que se refere ao conceito de homem natural do filósofo suiço. Segundo Rousseau, a infância teria maneiras de ver, pensar e sentir que lhes eram próprias, devendo a educação respeitá-las, e não contrariar suas inclinações, pois estas eram estabelecidas pela natureza. 
No caso do pensamento do barão De Gérando, podemos depreender que, ao mesmo tempo em que se constatavam diferenças no modo de funcionamento infantil, peculiares à idade, tais diferenças eram entendidas como ausência de elementos encontrados no adulto adequadamente instruído e ajustado de acordo com as normas sociais. De Gérando iria defender o papel da instrução na regulação das forças da natureza, inserido no debate que marcava a discussão da oposição natureza x cultura, que definia a produção da pedagogia ao longo do século XVIII. Conforme Rogério Fernandes (2000), "a criança e o jovem eram fortemente comandados a partir de interesses que interferem com as suas vidas de uma forma absoluta. Para os adultos, a criança não dispunha de capacidade para se reger de modo racional" (p. 92). Diante dessa concepção, a educação escolar constituiria a instância na qual se daria a preparação dessa criança para o mundo adulto.

A imagem da criança no mundo adulto ocidental moderno, cada vez mais atrelada à de aluno, ratificava o papel da educação escolar e da pedagogia como conformadoras de adultos (Boto, 2000). Assim, à criança era reservado o papel de aluno, segundo o qual seria submetida às intervenções educacionais, sendo formada e conduzida para ocupar um lugar no mundo adulto civilizado. Neste, muitas das características infantis não eram bem-vindas, devendo ser transformadas e/ou abolidas.

Os princípios pedagógicos presentes no manual do barão De Gérando eram referidos à obra de Locke. Este importante autor, apesar de tratar da educação voltada para o desenvolvimento de um gentleman em Some thoughts concernig education (1947), e, segundo Cambi (1999), "visto como modelo ideal para a nova classe dirigente inglesa do final do século XVII" (p. 316), desenvolveu os elementos centrais que sustentavam os princípios da educação dos alunos pobres na obra do barão De Gérando.

Ao referir-se às crianças advindas da aristocracia, Locke traçou o perfil do desenvolvimento de "um homem capaz de renunciar aos próprios desejos, de opor-se às próprias inclinações, e de seguir unicamente aquilo que a razão the indica como melhor, mesmo que os apetites lhe dirijam para outro lado" (apud Cambi, 1999, p. 317). De Gérando (1839), no caso das crianças pobres, afirmava:

[...] esses mesmos pobres meninos são levianos, travessos e inconstantes; cedem a todas as impressões; qualquer bagatella os irrita e assusta, e mil diversos accidentes lhes modificarão alternativamente a vivacidade, e he porisso que em vós não devem encontrar cousa semelhante, e que deveis dominar conter e pacificar esta disposição da infância com o predomínio de vosso caracter. (p. 27)

Constatamos, portanto, a presença de duas representações acerca da infância, que, sendo complementares, condicionavam o papel da educação escolar: a imagem da criança como ser imaculado e, ao mesmo tempo, ameaçado pelo mundo que a cercava; e a percepção de certas características componentes da natureza infantil, que, indesejadas, deveriam ser devidamente transformadas e adaptadas, características mais presentes nas crianças pobres, fruto da sua má formação doméstica. Entendia-se que a educação escolar teria a dupla função de proteger a infância das ameaças do mundo e transformá-la, formando-a nos moldes de um adulto civilizado.

A idéia de inferioridade também aparecia associada à imagem desses alunos pobres. Acreditava-se que a origem social e as precárias condições de existência às quais eram submetidos os influenciavam negativamente, conformando distintas características, físicas, emocionais e comportamentais. Como indica Geremek (1987), “nas sociedades modernas a pobreza não [é] apreendida unicamente como uma privação de bens materiais: ela corresponde a um estatuto social específico que por vezes marca mais fortemente a vida dos indivíduos do que a sua situação material desfavorecida" (p. 6). Segundo De Gérando (1839, p. 79),

Os meninos pertencentes a classes trabalhadoras e pouco abastadas viverão até alli em existencia monótona, pouco propria para mover a curiosidade; pouca parte tomarão nesse commercio de relações sociaes, poderoso meio 
de imprimir movimento na intelligencia; pouco virão e pouco ouvirão; são pouco curiosos, por lhes serem quase desconhecidos os prazeres da curiosidade. Deve o Professor procurar nesta intelligencia ainda tão fraca e inerte o principio de vida, excita-lo e po-lo em acção.

Percebe-se que a infância pobre era representada como contraposta a uma referência nitidamente baseada na da elite, sendo, portanto, vista como o negativo de uma infância modelo. A comparação com um modelo ideal de infância e a afirmação da inferioridade dos alunos pobres a partir desse padrão reforçava, por consequiência, a necessidade da educação escolar para suprir tais deficiências, originadas de uma vivência precária.

Nota-lo-heis, por outra parte, amados Ouvintes, quanto aos meninos de classes ricas, há uma especie d'educação, que resulta naturalmente da reunião das circunstancias em que estão postos. Cercados a todos os momentos dos productos da civilisação mais adiantada, o que vêem e o que ouvem lhes desperta o espirito, excita a sensibilidade, e fomenta de mil modos a actividade; elles observão e imitão. Não gozão os meninos das classes laboriosas de igual vantagem. Fora da Escola poucas occasiões tem de se formarem; e muitas para afrouxarem de milhares de modos. (idem, p. 46-47)

Nota-se a centralidade, na análise da formação do indivíduo, dos aspectos sensoriais. A partir de Locke e Condillac, constitui-se propriamente a corrente empirista sensualista que afirmava a importância do desenvolvimento dos sentidos na formação da razão. Nos meios desfavorecidos, a criança estaria exposta a uma "má formação" sensorial, prejudicial a esse desenvolvimento. Tanto Locke quanto Condillac defendiam que "o principal objeto dessa obra [Tratado das sensações] é de fazer vir como todos os nossos conhecimentos e todas nossas faculdades vem dos sentidos, ou, para falar mais exatamente, das sensações" (apud Banks-Leite \& Souza, 2000, p. 62).

A infância, tanto em Locke quanto em De Gérando, era considerada o momento em que o cará- ter deveria ser moldado, sendo pouco frutífero o empreendimento sobre a mudança de caráter no adulto, ${ }^{13}$ princípio traduzido na clássica metáfora de Locke de que as crianças seriam tábulas rasas. A melhor forma de concretizar essa proposta era pela formação de hábitos na criança e, com a indução à sua prática e freqüente repetição, buscar a sua perpetuação. Segundo De Gérando (1839, p. 290):

[...] o hábito he uma disposição adquirida, que facilita a execução de certos actos, que pode mesmo vir a ser tão forte que só ella possa reproduzir esses actos.

No seu entendimento, os hábitos atuariam sobre os órgãos exteriores, sobre a percepção e a vontade, tendo o professor das primeiras letras um importante papel na condução da educação das crianças, visto que as recebiam na fase da vida em que os hábitos começariam a ser formados.

O professor era, portanto, quem possuiria a responsabilidade de proteger a infância e formá-la dentro dos princípios educacionais estabelecidos, baseados, sobretudo, no desenvolvimento de qualidades morais e racionais. Sua conduta e seu caráter deviam, pois, ser irrepreensíveis. Para De Gérando (idem, p. 31):

Afaste-se fuja, não se anima a tocar na infancia, o que tiver coração corrompido! Bastaria seu hálito para contagiar aquelles tenros corações. Quem entregaria o deposito da innocencia a mãos impuras? [...] He a innocencia sanctuario cuja guarda se vos commette [...] há certo que de sancto neste bello ministério que adopta e protege a tenra idade.

A importância atribuída ao caráter dos professores e os cuidados em proteger a infância dos meios nocivos que a cercavam fundamentam-se na compreensão de que as experiências é que formariam o

${ }^{13}$ Nas palavras de Locke (1947, p. 211), "I imagine the mind of children as easily turned this that way as water it self". 
caráter e definiriam as condutas dos indivíduos. De Gérando indica a afinidade com os pensamentos de Locke também nesse aspecto: "Grande parte das características que diferenciariam os seres humanos entre si provém da educação que recebem" (idem, p. 210). Nesse sentido, para ambos os autores, o exemplo era visto como o principal meio de inculcar nessas crianças os hábitos desejados, já que eram consideradas "naturalmente inclinadas a imitar" e, pela imitação, "herda o menino com pouco custo a habilidade daquelles com quem vive". Essa forma de entender o funcionamento mental da infância produzia a necessidade de afastar de seu contato e convívio os exemplos considerados indesejáveis e perniciosos, uma vez que, na sua disposição para imitar,

[...] adopta o menino sem reflexão nem escolha todos os habitos dos que o rodeião. Eis, portanto, a importância, para aquele que deseja se dedicar ao magistério, do caráter e conduta irrepreensíveis, já que ele servirá de exemplo para as novas gerações. (p. 310-311)

Ao professor cabe "formar a infancia do homem" (idem, p. 41), tal qual imprimir sobre um papel branco as virtudes e os valores desejados. Segundo De Gérando (idem, p. 12),

[...] concedido vos foi lançar a primeira semente em terreno virgem; abrir os primeiros alicerces do edifício; recebeis a infancia ao sahir do berço, toda arraiada d'innocencia e candura para guia-la aos caminhos da sciencia e do bem.

$\mathrm{Na}$ análise dos discursos dos delegados de ensino da província mineira, percebe-se o eco de tal representação do papel do professorado:

[...] sendo a educação fundada inteiramente sobre a imitação, para formar homens não é necessário se não bem dirigir aqueles que devem lhes servir de modelos, a maior parte dos educandos, tendo alguns vestígios de semelhanças com seu educador, estes vestígios formarás o caráter nacional. (Minas Geras, 1838, envelope 73)
A centralidade do exemplo do adulto na formação da infância reforçava o papel da educação escolar das classes sociais inferiores. Tendo em vista o prejuízo advindo da sua inserção em meios formados por adultos não dotados de qualidades morais e de instrução que possibilitassem a formação de um indivíduo morigerado, a educação escolar afirmava-se como antídoto aos males do seu meio familiar. Assim, as qualidades morais dos professores constituíam um dos principais elementos a definirem seu perfil. Nota-se também a presença de referências religiosas na construção de um modelo de professor associado à santidade, extrema expressão de sua formação e conduta moral.

Percebemos, portanto, que as representações da infância pobre e os discursos em defesa da escolarização dessa infância reforçavam o movimento de construção e afirmação da educação escolar como locus privilegiado de formação dos futuros cidadãos civilizados. Porém, tal educação deveria dar-se em condições restritas, tendo em vista a necessidade de preparar essa infância para o lugar social quando adulto, de trabalhador em ofícios socialmente desvalorizados. Verifica-se a tensão na afirmação dessa educação escolar, por um lado, destacando sua importância, por outro, estabelecendo limites claros à sua efetivação.

É importante destacar que, no caso brasileiro, o processo de escolarização ao longo do século XIX não significou, como no caso dos países europeus, a extensão de um processo já em curso nas classes abastadas. No dizer de Veiga (2002, p. 101),

[...] diferentemente de outras nações, no Brasil a monopolização dos saberes elementares deu-se juntamente ao processo de monopolização da força física pelo Estado. Nesse aspecto, a ênfase da escolarização não se fez na busca de completar um processo de civilização já em curso, mas de estabelecer as civilidades e, principalmente, legitimar e dar visibilidade a uma nova forma de poder em construção.

\section{Instrução e educação nas escolas elementares}

O caráter fundamental do ensino destinado às camadas pobres da sociedade pautava-se na compreen- 
são de que o papel da escola não se limitaria a instruir, mas consistiria também, e principalmente, em educar. Como pudemos perceber, a discussão em torno do ensino dirigido aos alunos pobres referia-se predominantemente à formação do caráter e de hábitos, ao passo que pouco se destacavam os aspectos referentes aos conteúdos de ensino. E, mesmo quando eram discutidas formas de se proceder à transmissão do conhecimento, como nas polêmicas que envolviam os métodos de ensino, a preocupação com a disciplina, a ordem e a obediência sobressaíam em comparação com as discussões acerca dos conteúdos.

Instruir e educar, seus significados e as instâncias às quais eram atribuídas cada uma dessas funções passam por reconfigurações nesse processo de afirmação da escola na sociedade. Os discursos analisados neste trabalho apresentam, de forma bastante consensual, a idéia de que, para o ensino das classes pobres, a escola teria, sobretudo, o papel de educar. Nos dicionários de pedagogia, os verbetes educação e instrução aparecem sempre relacionados um ao outro, sendo ressaltada a idéia de que a educação deveria ser dada desde os primeiros momentos após o nascimento da criança, sendo, portanto, de responsabilidade dos pais. No que se refere à diferenciação dos dois conceitos, acreditava-se que o "fim da educação é desenvolver as faculdades moraes, enquanto a instrucção visa enriquecer as facultades intellectivas" (Campagne, 1886, p. 466, v. 1).

Segundo De Gérando (1839), a instrução voltada para os alunos pobres deveria "limitar-se essencialmente aos conhecimentos elementares" (p. 121). As razões para essa afirmativa dividem-se em dois tipos de argumentos. Um deles diz respeito à falta de tempo e da pouca utilidade da instrução em níveis mais elevados para os pobres, destinados ao mundo do trabalho. Um segundo tipo de argumento referiase aos riscos de dar aos pobres o acesso ao conhecimento, pelas possibilidades de incitação às desordens sociais. A crença no poder do conhecimento como propiciador de transformação social condicionava a necessidade de balizas para esse nível de ensino.
Essa tensão nos limites da educação das classes pobres já se fazia presente em Comenius, quando este comentava que a academia ou universidade "deveria ser freqüentada apenas pelos engenhos mais selectos a flor dos homens; os outros enviar-se á para a charrua, para as profissões manuais, para o comércio, para que aliás nasceram" (1675/1957, p. 39). A extensão da educação ao povo seria, no entanto, até o século XVIII, assumida essencialmente pela Igreja, não sendo compreendida como dever do Estado. Nesse sentido, a escolarização da população pobre era vista dentro dos limites da ação caritativa, a partir de um ethos religioso. Destaca-se La Salle, com sua escola para pobres, no século XVII, organizada em torno da educação religiosa e fundada numa rígida disciplina na ordenação dos processos pedagógicos, que contemplavam a aprendizagem de rudimentos de leitura e escrita. La Salle tinha em vista principalmente disciplinar o aluno, através de educação moral compreendida como formação religiosa. Sua pedagogia voltava-se basicamente para a construção de dispositivos de controle da população escolar e de aprendizagem de valores morais atravessados por um ethos religioso.

[...] es necesario que constituya vustro primer cuidado y primer efecto de vuestra vigilancia el ser atentos a vuestros alumnos para impedir que practiquem alguna acción, non solamente mala, incluso alguna inconveniente, haciendo que se abstengan de la menor aparencia de pecado. (La Salle apud Narodowski, 1998, p. 113)

Porém, com o século XVIII, progressivamente constituiu-se

[...] uma tendência em substituir a caridade religiosa ou particular, por uma beneficiência pública [...] entre os séculos XVI e XIX, o processo histórico de assistência social evoluiu dos modelos de caridade privada para o da política secularizadora, que confiava essa função aos poderes públicos. (Marcílio, 1998, p. 71)

Destaca-se, ao final do século XVIII e início do XIX, o trabalho de Pestalozzi, considerado como "el 
promotor y reformador de la escuella popular" (Cabanas, 1996, p. XV). Para Pestalozzi, o fim supremo da educação seria o fim moral. Segundo ele,

[...] la finalidad de la educación es la elevación de la persona a la verdadera dignidad propria de um ser espiritual. La educación convertirá al hombre em miembro útil de la sociedade haciéndolo autônomo pero hemos de tener presente que la autentica autonomia es cosa que va estrechamente unida al caracter moral. (apud Cabanas, 1996, p. XXI)

Ao lado da educação moral, a instrução assumia centralidade nas reflexões do autor, criando os princípios do chamado método intuitivo, que iria influenciar a produção pedagógica do século XIX e mesmo as teorias renovadoras da primeira metade do século XX.

Verifica-se a pregnância de uma referência religiosa e, mais propriamente, católica, no caso brasileiro. Na verdade, a educação moral, no contexto da província mineira, teria seus fundamentos em algumas estratégias. Por um lado, o ensino da religião, entendida como transmissão da doutrina católica; por outro, o exemplo do professor, bem como a transmissão de valores morais relacionados à formação do cidadão civilizado. Mas, principalmente, a própria escolarização, enquanto introdução de novos tempos e espaços na vivência da criança, regulados de acordo com uma economia moral definida pelo Estado.

Se a instrução deveria limitar-se aos níveis elementares da leitura, escrita e cálculo, a educação moral, considerada o principal ramo da educação (as outras dimensões seriam a educação física e a intelectual), deveria ser dada sem limites, uma vez que as famílias, em especial as das classes pobres, eram consideradas incompetentes no fornecimento das qualidades morais aos filhos. A escola representaria então a instância de sociabilidade responsável por recuperar os alunos da educação dos vícios à qual foram submetidos a partir da convivência familiar, e imprimir novos hábitos, adequados para estabelecer e manter a harmonia na estratificada sociedade imperial. Num relatório, um delegado de ensino assim se expressava ao presidente da província:
Tendo proposto a apresentar á V. Ex. uma noção verídica dos alunos das $1^{a}$ letras [...] porém com pouco fruto por não existirem em as aulas p.q. os pais em suas adolescências assim não versadas em princípios morais e civis destas instruções não tiveram semelhantes lições, por isso as não compulsão para um introduzir conhecimento ao que se deveria promover remédio, sem o que nenhum proveito podem obter para serem depois empregados em alguns dos serviços da Nação. (Minas Gerais, 1823, envelope 45)

Na verdade, ao longo do período estudado, a escola organizava-se principalmente em torno da educação moral, em consonância com os valores culturais do século XIX. No dizer de Elias (1994), faz-se presente "uma mudança muito considerável rumo ao tipo de controle das ânsias instintivas que o século XIX justificaria, acima de tudo, sob a forma de moralidade" (p. 171). Um dos pilares da educação moral, a força do exemplo do professor, significava que este deveria ser um indivíduo virtuoso, de moral ilibada. Assim, a província mineira exigia para a contratação de professores a apresentação de atestados de batismo e de boa conduta, encaminhados pelas autoridades do município (delegados, párocos, juízes), como os que seguem.

Atesto que a senhora [...] casada com o Sr. [...] é residente nesta cidade, vive honestamente com seu marido. No centro desta família tem tido boa conduta, moralidade, regular procedimento e goza por isso a instrução publica nesta cidade o que afirma sua fé no cargo que ocupa pelo pleno conhecimento que da mesma senhora eu tenho e ser de notoriedade publica. E por ser verdade e isto ser me pedido mandei lavrar o presente. (Minas Gerais, 1875)

Atesto que o Exmo. Sr. Daniel residente nesta cidade é um cidadão de bons costumes e por ter boa conduta é estendido o que por seu conhecimento que do mesmo tenho e afirmo. Atesto que tem bom comportamento civil, moral e religioso. (Minas Gerais, 1877)

A centralidade da formação católica, requisito para a educação moral, fazia com que o ensino da 
doutrina católica fosse transformado em disciplina escolar, com o uso de compêndios de doutrina, material freqüente nas escolas, segundo relato dos delegados. Todavia, a incorporação de práticas religiosas católicas à cultura escolar nascente fazia da escola espaço de culto e devoção.

[...] eu mesmo tomei muitas lições dos alunos e juntamente perguntei-lhes a doutrina cristã como também vi os escritos das mesmas pelo que fiquei muito satisfeito de ver o grande aumento que em tão pouco tempo os alunos tem se aproveitado com o novo professor que os conduz ao verdadeiro procedimentos dos deveres de católico e da humanidade, levando-os aos domingos e dias santos em sua companhia á missa, e nas tardes destes dias rezando com eles o terço representam grande obediência, pelo que julgo enemérito de exercer no emprego. (Minas Gerais, 1837)

Rellação de meninos q actualmente frequentão a Es-colla das primeiras Letras nesta $C^{\text {a }}$. Do Paracatu do $\mathrm{Pr}^{\mathrm{e}}$

1. Manoel Ferreira a anno, e 3 mezes escrevendo Letra fina contando conta de multiplicar por 3 letras, e bem desembaraçado no Ler letra da mão e redonda, e na explicação da reza e no ajudar da Missa, e o d he pardo.

2. Francisco Glz de $\mathrm{Carv}^{\circ}$ branco 1 anno, e 2 mezes principiando escrever Letra fina, e contando conta de multiplicar por 3 Letras, e já Lê letra de mão redonda, e bem adiantado na explicação da reza e no ajudar da Missa. (Minas Gerais, 1823)

A transmissão da doutrina católica era associada à de valores civis, voltados para a introjeção de uma ordem pública, denominada catecismo civil. É possível constatar, no relatório do presidente de província Bernardo Jacintho da Veiga, de 1823, a presença de uma visão ideologizada de educação que, segundo Cambi (1999), atravessa o século XIX. Ao explicitar os conteúdos necessários para o ensino primário, afirmava ser fundamental que os alunos aprendessem, além da doutrina cristã, os deveres da sociedade a partir de um outro Cathecismo civil. Segundo ele,

Este cathecismo deve ser seguido de hum Código em forma de Regulamento, em que se declarem simplesmente os castigos correspondentes aos crimes. De taes Cathecismos devem banir-se as palavras enganadoras de liberdade, e igualdade, com que se costuma engodar o povo rude, por que essas liberdade, e igualdades ninguém as deve tomar por si mesmo. As authoridades, he que devem ser obrigadas sustenta-las em virtude da Lei. (Minas Gerais, 1823, envelope 28)

Verifica-se que se tinha em vista a aprendizagem e introjeção de uma determinada ordem social, que naturalizava a desigualdade, a atribuição da autoridade e da lei ao Estado, ao qual as camadas pobres deveriam ser subservientes, expressa numa doutrina civil que tinha na escola um dos espaços principais de difusão. Outro recurso utilizado na escola para aprendizado de noções morais relacionadas à formação do cidadão era a leitura e cópia da Constituição, o que buscava também contribuir para a construção do sentimento de nacionalidade. Segue atestado do juiz de paz que presenciou o exame público de meninos:

[...] achei terem os alunos bastante aproveitamento, pois foram argüido em princípios de Religião Catholica Apostólica Romana, gramatica nacional, arithmetica, ler, escrever, e finalizou-se com reflexões acerca da constituição o que tudo muito satisfez a todos os assistentes. (Minas Gerais, 1838, envelope 38)

Além disso, assinalava-se a necessidade de produzir materiais didáticos que possibilitassem a educação moral, compreendida, também, como conteúdo escolar.

Fala-se da necessidade de se investir na Instrução Publica para que se publique e imprima-se um compêndio que contenha extremadas noções gerais e mais puras idéias de religião, moral, e as da importância da união e integridade do Império que os artigos $1^{\circ}$ e $4^{\circ}$ da citada lei $n^{\circ} 13$ incumbe 
os professores do $2^{\circ}$ grau ensinarem a seus alunos, recomenda aos delegados façam observar a custa dos maiores sacrificios. (Minas Gerais, 1838, envelope 73)

Verifica-se também uma tensão na definição do conteúdo a ser transmitido nesse catecismo civil. Enquanto o presidente da província assinalava os perigos advindos da transmissão de certos valores, como igualdade e liberdade, estes se faziam presentes nas escolas, nos relatos dos delegados de ensino:

Escrita dos alunos: "A virtude, a honra e a probidade se conseguem conformando todas as nossas ações com as leis naturais e sociais. Não há crime mais enorme que trair a própria patria, nem coisa tão notável como a ingratidão". (Joaquim Leandro, 8/10/1833)

Ninguém pode ser feliz em um governo despótico, porque é este um monstro, que devora seus filhos. O despotismo é contrario ao fim das sociedades civis, e posto á vontade de Deus que criou o homem livre para ser feliz. (Minas Gerais, 1837, envelope 23)

Cabe analisar que a afirmação da necessidade da extensão da escola às classes laboriosas revela a polêmica presente, ao longo desse período histórico, em torno dos reais benefícios e os possíveis perigos advindos da instrução. No jornal $O$ Universal, de tendência liberal, essa polêmica aparece em matérias que construíam argumentos enfatizando a importância de instruir o povo, contrapondo-se a interlocutores que nitidamente não possuíam a mesma opinião. Em 17 de fevereiro de 1826, lia-se, em parte de uma extensa matéria que ocupara diversos números seguidos, argumentos relacionando conhecimento e poder:

He indubitavel que há hum genero de instrucção, a qual todos devem possuir, e que há outra que só compete a certos individuos. O que se destina aos trabalhos do campo, ou á manipulação das officinas não carece de ser instruido no mesmo gráo como o que se destina a arte militar, ou ao governo da republica. Mas até hum certo ponto, consideravel gráo de illustração póde extender-se a todas as classes; [...] Todavia ainda hoje há quem affirme, que a intelligencia, e as luzes, são qualidades que não he muito para desejar sejão possuidas pela Grande massa do Povo... Não sei como há quem tenha tanto medo ás luzes; só se isso vem de que, sendo certo que o saber he poder... há muitos que temem este poder; porque póde dar ao mechanismo politico da associação huma nova forma que transforme os seus interesses; por certo que em a massa geral de huma associação sendo illustrada deixará de se dividir [como até aqui] em duas classes somente, huma das quaes opprima, e a outra soffra. Este foi o estado do Brasil até hum certo período [...]. (p. 3-4, grifos do original)

Já em 14 de junho de 1841, um argumento de outra natureza pretendia defender o mesmo ponto em questão: a escolarização como estratégia para o refreamento das paixões.

Trataremos hoje a questão importante - se será ou não perigoso o ensino e a instrucção nas classes inferiores da sociedade? - Há quem receie esta instrucção nos operarios, nos trabalhadores, no povo em fim; nós somos de opinião contraria, e estamos profundamente convencidos de que o perigo não está no povo instruido, mas sim no povo ignorante; [...] é ou não util instruir o povo? - Nós repetimos - sim - porque o aperfeiçoamento da rasão humana conduz ao refreamento das paixões, e estas são mais temiveis em espiritos incultos do que naquelles em que a educação penetrou: a ignorancia é a companheira da anarchia e da demagogia; quando por outra parte se tem observado que os habitos de reflexão, que são inseparaveis do gosto da leitura, ajudão e favorecem o espirito de ordem e bom procedimento nos que a ella se dedicão. - É entre os automatos, que vegetão como animaes nas ultimas classes da sociedade, que se achão os agitadores, e os desordeiros [...]. Uma insurreição feita por pessoas serias e instruidas seria impraticavel. Regra geral, a instrucção é a mãi da prudencia; o selvagem é imprudente e imprevidente por que é ignorante; a previdencia e a reflexão seguem necessariamente nas naçõens, assim como nos individuos, o progresso da civilisação e da instrucção; [...] A educação aperfeiçoa a sociedade, não só por que dá habito e costumes de regularidade, mas tambem por que substitue esses máus cos- 
tumes pelos bons; [...] - Em summa, na marcha actual das sociedades europeas o que nos parece util, o que nos parece necessario e indispensavel é o proporcionar ao povo uma instrucção solida fundada na sciencia e na religião. (p. 1-2)

Como aponta Veiga (2002), se até o século XVIII produziu-se uma pedagogia voltada para a difusão de um comportamento civilizado entre as classes abastadas, marcado, entre outros fatores, pelo autocontrole na manifestação das pulsões, no século XIX afirmouse a escolarização, em que o autocontrole seria estendido aos demais grupos sociais, como condição de civilização. Segundo a autora,

[...] a grande revolução do século XIX foi exatamente a substituição da pedagogização das relações sociais pela escolarização; mais que tornar gestos e ações previsíveis, foi preciso indicar o caminho da produção da previsibilidade, não mais para um grupo restrito, cuja aprendizagem parecia estar concluída, mas para toda a sociedade. Portanto, a realização plena da civilização pressupõe ser civilizado como razão universal, mas, mais que isso, como uma manifestação interior de cada um e não como algo imposto do exterior. (p. 99-100)

Tal polêmica, os riscos da ilustração, mostra-se característica desse período histórico, ante o temor de sublevação das camadas sociais inferiores. Tanto na Europa, quanto no Brasil, o registro de revoltas sociais de maior ou menor porte, desde a Revolução Francesa, demonstra um quadro de tensão social, ante a qual a escola poderia ser compreendida não como fator de agregação, mas de possibilidade de promoção de revolta. A educação escolar pretendia contribuir para o aprendizado do lugar social numa sociedade rigidamente estratificada, e a conformação com essa condição. Entretanto, podemos dizer que o projeto de educação civilizatória tinha pretensões mais ousadas. A infância era vista como intermediária entre a escola e a sociedade, o que levava à crença de que a aprendizagem proporcionada pela escola seria disseminada primeiramente no meio familiar, beneficiando posteriormente a sociedade como um todo.
Para o barão De Gérando (1839), a educação da infância era entendida como o primeiro passo para a constituição de uma nação livre.

[...] o menino que volta da Escola, imbuído nos saudáveis effeitos de boa educação, derramará perfumes desta em volta de si na casa paterna; dará Candido testemunho á virtude; obrará ás vezes até sobre a família insensivelmente, mas com efficacia; seus exemplos allumiarão, moverão os pais; seu commercio os melhorará; e talvez que até os desvie dos habitos viciosos a que se havião entregue. (p. 49)

\section{Conclusão}

O estudo do processo de escolarização ao longo do período indicado suscita questões acerca de uma compreensão mais detalhada da institucionalização da escola ao longo do século XIX. Percebe-se algumas questões que caracterizam a primeira metade do século, como a polêmica acerca da propriedade de extensão da instrução à população pobre da província. Se essa discussão fez-se fortemente presente nas fontes analisadas, parece ter sido posteriormente superada, tornando-se hegemônica a visão da importância da educação elementar dessa faixa da população. Isso não quer dizer, no entanto, que tenham sido efetivados dispositivos concretos e eficazes de inserção e manutenção da criança pobre na escola. Embora na província mineira o número de alunos atendidos tenha aumentado significativamente na segunda metade do século, tal contingente, segundo Faria Filho (2001), representava apenas $1 \%$ da população a ser escolarizada.

É importante destacar que se a obrigatoriedade escolar foi assumida na legislação mineira e de outras províncias contemporaneamente em relação aos países europeus; nestes, em termos gerais, foi compreendida como dever do Estado, e não como responsabilidade dos governos provinciais, o que parece ter contribuído para permitir sua efetivação.

Quanto à centralidade da educação moral, esta destaca-se como característica do período estudado. $\mathrm{Na}$ 
segunda metade do século XIX, os avanços científicos iriam influenciar a ordenação do currículo das escolas elementares, com a entrada de novas disciplinas, como história e geografia nacionais, bem como o adensamento dos conteúdos das disciplinas anteriormente presentes. Começa a configurar-se um conjunto de saberes próprios à instituição escolar, que, na primeira metade do século XIX, se mostrava ainda pouco definido, demonstrando o processo de conformação de uma cultura escolar que singulariza a instituição e, ao mesmo tempo, contribui para a constituição desta como "a forma mais adequada e socialmente válida de formação das novas gerações." (Faria Filho, 1998, p. 148). Nesse processo, a escola é, ao mesmo tempo, produto da sociedade e produtora dela, e o aluno aparece como o resultado dessa forma escolar de socialização, concorrendo com a criança e subordinando-a como elemento secundário. É, portanto, papel da escola formar o aluno não somente no que se refere ao saber, mas também, e principalmente, ao ser (Chervel, 1990, p. 186); eis, portanto, por que não houve o abandono da educação moral a partir da segunda metade do século XIX. Ela fez-se presente ao longo de todo o século. Na verdade, a atribuição de uma educação moral à escola voltada para as camadas populares, fruto de uma suposta incapacidade de as famílias desses estratos exercê-la, constitui um discurso que tem permanência na escola contemporânea.

Verifica-se um deslocamento nos eixos explicativos da suposta precariedade das famílias das camadas populares no exercício da educação intelectual e, principalmente, moral da infância, bem como um deslocamento nos instrumentos escolares e sociais de intervenção nesse meio social. Porém, persiste uma representação negativizada dessas famílias, representação que se estende ao aluno advindo das camadas pobres da população.

\section{Referências bibliográficas}

ALENCASTRO, L. F. Vida privada e ordem privada no Império. In: ALENCASTRO, L. F. (Org.). História da vida privada no Brasil. São Paulo: Companhia das Letras, 1997. p. 11-94, v. 2.
BANKS-LEITE, L.; GALVÃO, I. Uma introdução à história de Victor do Aveyron e suas repercussões. In: BANKS-LEITE, L.; GALVÃO, I. (Orgs.). A educação de um selvagem. São Paulo: Cortez, 2000. p. 11-24.

BANKS- LEITE, L.; SOUZA, R. M. O des(encontro) entre Itard e Victor: os fundamentos de uma educação especial. In: BANKSLEITE, L.; GALVÃO, I. (Orgs.). A educação de um selvagem. São Paulo: Cortez, 2000. p. 57-82

BASTOS, M. H. C. Formação de professores para o ensino mútuo no Brasil. O curso normal para professores de primeiras letras do barão De Gérando (1839). In: BASTOS, M. H. C.; FARIA FILHO, L. M. de (Orgs.). A escola elementar no século XIX - o método monitorial/mútuo. Passo Fundo: EDIUPF, 1999. p. 239-269.

BASTOS, M. H. C.; FARIA FILHO, L. M. de (Orgs.). A escola elementar no século XIX - o método monitorial/mútuo. Passo Fundo: EDIUPF, 1999.

BOTO, C. O desencantamento da criança: entre a Renascença e o século das Luzes. In: FREITAS, M. C.; KUHLMANN JR., M. (Orgs.). Os intelectuais na história da infância. São Paulo: Cortez, 2002. p. 11-60.

CABANAS, J. M. Estúdio preliminar in Pestalozzi, Johann H. Cartas sobre educación infantil. Madrid: Tecnos, 1996.

CAMBI, F. História da pedagogia. São Paulo: UNESP, 1999.

CARVALHO, J. M. de. Pontos e bordados. Ensaios de história política. Belo Horizonte: UFMG, 1998.

CHERVEL, A. História das disciplinas escolares: reflexões sobre um campo de pesquisa. Teoria \& Educação, n. 2, p. 177-229, 1990.

DUARTE, R. H. Noites circenses. Campinas: UNICAMP, 1995.

ELIAS, N. O processo civilizador: uma história dos costumes. Rio de Janeiro: Zahar, 1994.

FARIA FILHO, L. M. de. Cultura e prática escolares: escrita, aluno e corporeidade. Cadernos de Pesquisa, n. 103, p. 136-149, 1998.

. História da política educacional em Minas Gerais no século XIX: os relatórios dos presidentes da Província. Revista Brasileira de História da Educação, n. 2, 2001.

Processo de escolarização no Brasil: algumas considerações e perspectivas de pesquisa (Síntese de pesquisa). Belo Horizonte: Faculdade de Educação / UFMG, s.d. Mimeografado.

FARIA FILHO, L. M. de; SOUZA, L. C. B. O jornal como fonte para a história da educação: um estudo sobre jornais mineiros do século XIX. In: CONGRESSO LUSO-BRASILEIRO DE HISTÓ- 
RIA DA EDUCAÇÃO, 2., São Paulo. Anais... São Paulo: Comunicação, 1998. p. 144-151.

FERNANDES, R. Notas em torno de retratos de criança. Educação e Pesquisa,v. 26, n. 1, p. 87-97, 2000.

FRANCO, L. A. C. A escola do trabalho e o trabalho da escola. São Paulo: Cortez /Autores Associados, 1997.

GEREMEK, B. A piedade e a forca - história da miséria e da caridade na Europa. Lisboa: Terramar, 1987.

GOUVÊA, M. C. S. de. A educação da "meninice" nas Minas oitocentistas e a produção da individualidade do aluno. In: VEIGA, C. G.; FONSECA, T. N. (Orgs.). História e historiografia da educação no Brasil. Belo Horizonte: Autêntica/CNPq, 2003. p. 89-226.

. Meninas nas salas de aula: dilemas da escolarização

feminina no século XIX. In: FARIA FILHO, L. M. de (Org.). A infância e sua educação: materiais, práticas e representações. Belo Horizonte: Autêntica, 2004. p. 157-182

JINZENJI, M. Y. A escolarização da infância pobre nos discursos educacionais em circulação em Minas Gerais (1825-1846). Dissertação (Mestrado) - Faculdade de Educação da Universidade Federal de Minas Gerais, 2002.

KUHLMANN JR., M. Infância e educação infantil: uma abordagem histórica. Porto Alegre: Mediação, 1998.

LEITE, M. M. A infância no século XIX segundo memórias e livros de viagem. In: FREITAS, M. C. de (Org.). História social da infância no Brasil. São Paulo: Cortez, 1997. p. 17-50.

MARCÍLIO, Maria Luiza. História social da criança abandonada. São Paulo: Hucitec, 1998.

MATTOS, I. R. de. O tempo Saquarema: a formação do Estado Imperial. Rio de Janeiro: Access, 1994.

MUNIZ, D. do C. Um toque de gênero: história e educação em Minas Gerais (1835-1892). Brasília: Editora Universidade de Brasília / FINATEC, 2003.

NARODOWSKI, M. Infância e poder: conformação da pedagogia moderna. Bragança Paulista: Editora da Universidade São Francisco, 1998 .

RIZZINI, I.; FONSECA, M. T. Bibliografia sobre a história da criança no Brasil. Marília: UNESP, 2001.

ROSA, W. M. Instrução pública e profissão docente em Minas Gerais (1825-1852). Dissertação (Mestrado) - Faculdade de Educação, Universidade Federal de Minas Gerais, Belo Horizonte, 2001.
SILVA, W. Liberais e povo: a construção da hegemonia liberalmoderada na Provícia de Minas Gerais (1830-1834). Tese (Doutorado em História) - Programa de Pós-Graduação em História, Instituto de Filosofia e Ciências Sociais, Universidade Federal do Rio de Janeiro, Rio de Janeiro, 2002.

SOUZA, L. de M. e. Opulência e miséria das Minas Gerais. São Paulo: Brasiliense, 1986.

VEIGA, C. G. Crianças negras e mestiças no processo de institucionalização da instrução elementar, Minas Gerais, século XIX. In: CONGRESSO BRASILEIRO DE HISTÓRIA DA EDUCAÇÃO, 3., Curitiba. Anais... Curitiba: Pontifícia Universidade Católica do Paraná, 2004.

. A escolarização como projeto de civilização. Revista Brasileira de Educação, v. 21, p. 90-103, 2002.

Fontes primárias manuscritas

MINAS GERAIS. Instrução Pública. Ofícios dos Delegados dos Círculos Literários ao Governo (segundo trimestre). Seção Provincial $n^{\circ} 233,1839$ a.

MINAS GERAIS. Instrução Pública. Ofícios dos Delegados dos Círculos Literários ao Govêrno (terceiro trimestre). Seção Provincial $\mathrm{n}^{\circ} 234,1839 \mathrm{~b}$.

MINAS GERAIS. Instrução Pública. Ofícios dos Delegados dos Círculos Literários ao Governo (quarto trimestre). Seção Provincial $\mathrm{n}^{\circ} 235,1839 \mathrm{c}$.

MINAS GERAIS. Instrução Pública. Ofícios de Professores Primários ao Govêrno. Seção Provincial no 236, 1839d.

MINAS GERAIS. Instrução Pública. Portarias da Presidência aos Delegados Literários. 1839-1840. Seção Provincial n² 267, 1839-1840. MINAS GERAIS. Requerimentos (primeiro trimestre). Seção Provincial $n^{\circ} 274,1840$.

MINAS GERAIS. Instrução Pública. Ofícios do Govêrno sôbre Instrucção Pública e Delegados Literários. Seção Provincial $n^{\circ} 304,1841-1843$.

MINAS GERAIS. Instrução Pública. Ofícios sôbre Instrucção Pública. Seção Provincial no 360, 1844-1850.

MINAS GERAIS. Presidência da Província. 1/42 Caixa 1, 1823. MINAS GERAIS. Presidência da Província. 1/42 Caixa 1, 1830.

MINAS GERAIS. Presidência da Província. 1/42 Caixa 12, 1838. MINAS GERAIS. Presidência da Província. 1/42 Caixa 9, 1837. 
MINAS GERAIS. Instrução Pública. Caixa 14, 1875.

MINAS GERAIS. Instrução Pública. Caixa 14, 1877.

\section{Fontes primárias impressas}

BRASIL. Instrução Pública. Lei de 15 de outubro de 1827. Collecção das Leis do Imperio do Brazil de 1827. Rio de Janeiro: Typographia Nacional, 1878.

BUISSON, F. Dictionnaire de pédagogie et d'instruction primaire. Paris: Librairie Hachatte et Cie., 1887. Tomo I, Tomo II.

CAMPAGNE, E. M. Diccionario universal de educação e ensino. Porto: Livraria Internacional de Ernesto Chardon. Casa Editora Lugan \& Genelioux, successores, 1886. Tomo I, Tomo II.

COMENIUS, J. A. Didática magna. São Paulo: Martins Fontes, 1997 (1ª edição em 1657).

DE GÉRANDO, J. M. Curso normal para professores de primeiras letras ou direcções relativas á educação physica, moral e intellectual nas escolas primarias. Nictheroy: Typographia Nictheroy, 1839 (exemplar microfilmado, 412 p.).

LOCKE, J. Some thoughts concerning education. In: PENNIMAN, H. R. (Org.). On politics and education. New York: D. Van Nostrand, 1947 (1ª edição em 1693).

MINAS GERAIS, (1835). Instrução Pública. Lei no 13 de 28 de março. Livro das Leis Mineiras. Ouro Preto: Typografia de Silva, 1846.

MINAS GERAIS, (1835). Instrução Pública. Regulamento nº 3 da Lei $\mathrm{n}^{\circ} 13$ de 22 de abril. Livro das Leis Mineiras. Ouro Preto: Typografia de Silva, 1848.

MINAS GERAIS, (1835-1846). Instrução Pública. Seção Provincial. Relatórios de Presidente de Província. Arquivo Público Mineiro.

O UNIVERSAL. Ouro Preto: Hemeroteca de Belo Horizonte, 1825-1842. Semanal

ROUSSEAU, J.-J. Emílio. Ou da Educação. 2. ed. São Paulo: Martins Fontes, 1999 (1ª edição em 1762).

SILVA, A. de M. Dicionário da lingua portuguesa. 5. ed. Lisboa: Typographia de Antonio José da Rocha, 1844. Tomo I, Tomo II.

MARIA CRISTINA SOARES DE GOUVÊA, doutora em educação pela Universidade Federal de Minas Gerais (UFMG), com pós- doutorado em História da Educação na Universidade de Lisboa, é professora do Programa de Pós-Graduação em Educação da UFMG, onde é membro do Grupo de Estudos e Pesquisas em História da Educação (GEPHE) e pesquisadora-bolsista do Conselho Nacional de Desenvolvimento Científico e Tecnológico (CNPq). Últimas publicações: em co-autoria com Carlos Henrique Gerken, Vygotsky e a psicologia sócio-histórica (In: FARIA FILHO, L. M (Org.). Pensadores sociais e história da educação. Belo Horizonte: Autêntica, 2005. p. 119-139), O mundo da criança: a construção do infantil na literatura brasileira (Bragança Paulista: Editora São Francisco, 2004); Meninas nas salas de aula: dilemas da escolarização feminina no século XIX (In: FARIA FILHO, L. M. de (Org.). A infância e sua educação: materiais, práticas e representações (Belo Horizonte: Autêntica, 2004. p. 189-212); A educação da "meninice" nas Minas oitocentistas e a produção da individualidade do aluno (In: VEIGA, C. G.; FONSECA, T. N. (Orgs.). História e historiografia da educação no Brasil (Belo Horizonte: Autêntica/CNPq, 2003. p. 189-226). Pesquisas em desenvolvimento: Pesquisa integrada: "História da infância Portugal/Brasil: materialidades, práticas, representações (1820-1950)", com financiamento CAPES/ ICCTI; "A conformação da idade escolar nos discursos científicos e nas práticas pedagógicas (1880-1910)", com financiamento do CNPq. E-mail: crisoares43@yahoo.com.br

MÔNICA YUMI JINZENJI, doutoranda em educação na UFMG, Bolsista do CNPq, Pesquisadora do Grupo de Estudos e Pesquisas em História da Educação (GEPHE). Últimas publicações: Cartas sobre a educação das meninas por huma sra americana: um manual para a formação de professoras primárias (1838) (In: CONGRESSO BRASILEIRO DE HISTÓRIA DA EDUCAÇÃO, 3. Anais... Curitiba, 2004, p. 1-15. 1 CD-ROM); A escolarização da infância pobre nos discursos educacionais em circulação em Minas Gerais (1825-1846) (In: GOUVÊA, M. C. S. de; VAGO, T. M. (Orgs.). Histórias da educação: histórias de escolarização. Belo Horizonte: Horta Grande, 2004. p. 53-65); A infância e sua educação: materiais, práticas e representações (Portugal e Brasil) (Estilos da Clínica, resenha, v. IX, n. 17, p. 128-134, 2004). Pesquisa em desenvolvimento: "A interlocução entre o periódico $O$ Mentor das Brasileiras e outros textos na produção e difusão de representações de gênero - Minas Gerais, 1829 a 1832”. E-mail: monicajinzenji@ig.com.br

Recebido em fevereiro de 2005 Aprovado em outubro de 2005 
gumas vezes até contraditória, com essa ideologia. O foco do nosso trabalho é a produção bibliográfica do grupo de educadores que se articulava em torno de Anísio Teixeira, à época diretor do Instituto Nacional de Estudos Pedagógicos (INEP), órgão vinculado ao Ministério da Educação e Cultura (MEC). De uma forma geral, pode-se afirmar que a apropriação do pragmatismo deweyano, nesse contexto, deu-se numa tripla perspectiva: o pragmatismo como método científico, implicando uma determinada concepção de ciência, particularmente das ciências sociais, com ênfase na aplicação do conhecimento científico na solução dos problemas de ordem prática; como modo de vida democrático; e como sinônimo de experimentalismo, no âmbito da escola. Palavras-chave: pragmatismo; desenvolvimentismo; pensamento educacional brasileiro; história da educação; política científica.

Pragmatism and developmentalism in Brazilian educational thought in the 1950's and 1960's

This article proposes to analyse some aspects of the appropriation of New

School thinking in Brazil, particularly Deweyan pragmatism, in the 1950's and 1960's. The analysis is based on the assumption that the developmentalist ideology which punctuated the debate on the economic, political and social restructuring of the country during these two decades constituted a fertile ground for the return and expansion of pragmatist thinking amongst Brazilian educators, articulating itself, sometimes in contradictory ways, with this ideology. The focus of this analysis is on the writings of that group of educators which circulated around the figure of Anísio Teixeira, at the time director of the National Institute for Pedagogic Studies (INEP), an organ linked to the Ministry of Education and Culture
(MEC). In general, could be stated that the Deweyan pragmatism

appropriation, in this context, happened according to tree perspectives: the pragmatism as cientific method, presupposing a certain conception of science, specially of social science, focusing on the applications of scientific knowledge on the solution of practical problems; as democratic style of life; and as synonym of experimentalism, in school environment.

Key-words: Pragmatism;

developmentalism; Brazilian

educational thought; history of

education; scientific policy

Pragmatismo y desenvolvimiento en el pensamiento educacional brasileño de los años 1950/1960

El artículo analiza las formas de apropiación del ideario de la Escuela Nueva en Brasil, particularmente del pragmatismo deweyano, en los años de 1950/1960. Se parte de la suposición de que la ideología desenvolvimentista que marcó el debate en torno de la reestructuración económica, política y social del país, en esas dos décadas, se costituyó en un suelo fértil para la retomada y la expansión del ideario pragmatista entre los educadores brasileños, articulándose de forma algunas veces hasta contradictoria, con esa ideología. El foco de nuestro trabajo es la producción bibliográfica del grupo de educadores que se articulaban en torno de Anísio Teixeira, en la época era director del Instituto Nacional de Estudios Pedagógicos (INEP), órgano vinculado al Ministerio de Educación y Cultura (MEC). De forma general se puede afirmar que la apropiación del

pragmatismo deweyano, en ese contexto, se dió en una triple perspectiva: el pragmatismo como método científico, implicando en una determinada concepción de ciencia, particularmente de las ciencias sociales, con énfasis en la aplicación del conocimiento científico en la solución de los problemas de orden práctica; como modo de vida democrático, y como sinónimo de experimentalismo, en el ámbito de la escuela.

Palabras claves: pragmatismo; desenvolvimentismo; pensamiento educacional brasileño; historia de la educación, política científica

Maria Cristina Soares de Gouvêa e Mônica Yumi Jinzenji

Escolarizar para moralizar: discursos sobre a educabilidade da criança pobre (1820-1850)

$\mathrm{O}$ artigo busca analisar os discursos sobre a educação da infância pobre presentes na província mineira na primeira metade do século XIX, investigando as concepções sobre a educabilidade da criança dos estratos sociais inferiores e seu papel na formação de uma nação civilizada. Esta criança era representada como possuindo faculdades mentais e qualidades morais diferenciadas das crianças dos estratos superiores, fruto de sua pertinência social, a serem reparadas pela educação escolar. Assim, definia-se um projeto de escolarização voltado para esse segmento da população, fundado na instrução, circunscrita ao ler, escrever e contar, e principalmente na educação moral, condição de formação de um adulto civilizado.

Palavras-chave: história da infância; história da educação; infância pobre

Education as a process of moralisation: discourses on the educability of poor children (18201850)

This paper analyses the discourse on the education of poor children which was present in the Province of Minas Gerais during the first decades of the $19^{\text {th }}$ century. It discusses the conceptions concerning the possibilities of educating poor children and the importance of education for the creation of a civilised 
nation. Such children were characterised as possessing mental faculties and moral qualities different from those children from the upper classes. These differences were attibuted to by their social experience and could be corrected by school education. Thus, a school project was defined for this segment of the population based on instruction restricted to reading, writing and arithmetic and above all on moral education, the baseline for turning them into civilised adults.

Key-words: history of childhood; history of education; poor childhood

Escolarizar para moralizar: discursos sobre la educación del niño pobre (1820-1850)

El artículo busca analizar los discursos sobre la educación de la infancia pobre, presentes en la Provincia minera, en la primera mitad del siglo XIX, investigando las cocepciones sobre la educación del niño de las clases sociales inferiores y su papel en la formación de una nación civilizada. Este niño era representado como poseedor de facultades mentales y cualidades morales diferentes de los niños de clases sociales superiores, fruto de su pertinencia social, a ser reparadas por la educación escolar. Así, se definía un proyecto de escolaridad, sólo para ese segmento de la población, fundamentado en la instrucción circunscripta al leer, escribir y contar, principalmente en la educación moral, condición de formación de un adulto civilizado.

Palabras claves: historia de la infancia; historia de la educación; infancia pobre

Marcio da Costa e Mariane Campelo Koslinski

Entre o mérito e a sorte: escola, presente e futuro na visão de estudantes do ensino fundamental do Rio de Janeiro

$\mathrm{O}$ artigo apresenta resultados de uma pesquisa, intitulada "Educação e exclu- são social - o sagrado sob ameaça", que procura identificar fatores que influiriam na formação de apreciações valorativas mais ou menos favoráveis à escola. A hipótese básica da investigação propõe a existência de um esvaziamento do significado do espaço escolar, para alguns setores sociais longamente expostos a um processo de redução das oportunidades de mobilidade social ascendente, pelas vias características das sociedades modernas. Um breve relato da pesquisa com estudantes do Rio de Janeiro é apresentado, bem como sua metodologia - que envolve grupos focais e survey - e uma revisão de literatura aparentada ao problema, a qual antecede a exposição de resultados obtidos por meio dos grupos focais realizados. Os dados sistematizados tendem a fortalecer a hipótese principal: a escola parece um elemento dúbio e questionável para a parcela mais "excluída" dos estudantes ouvidos. Porém, há circunstâncias que confundem este quadro, acentuando a experiência escolar como um aspecto central do valor atribuído pelos estudantes à escola e, de certa forma, contrabalançando os efeitos disruptivos de um quadro econômico de agudos conflitos sociais associados a padrões de desigualdade social extremos e duradouros.

Palavras-chave: sociologia da educação; valor social da educação; juventude e educação; exclusão social; sagrado social

Between merit and luck: school, present and future, in the eyes of high school students from Rio de Janeiro

The paper presents the results of a research, entitled "Education and social exclusion - the sacred under threat", which seeks to identify factors influencing the construction of a more or less favourable value appreciation of school. The main hypothesis of the investigation is that the meaning of the school space is weakening, for some social sectors long exposed to a process of reduction of opportunities for ascendant social mobility through the distinctive channels of modern societies. A brief report of the research focusing on students from Rio de Janeiro is presented, as well as its methodology - which involves focus groups and a survey -, and a literature review related to the issue. The systematised data tend to strengthen the main hypothesis: the school seems to be a dubious and questionable element for the most excluded segment of the students researched. Nevertheless, there are circumstances that confuse this picture, accentuating the school experience as a central aspect of the value attributed by students to school and, in a way, counterbalancing the disruptive effects of an economic framework of deep social conflicts associated with patterns of extreme and long-lasting social inequality.

Key-words: sociology of education; social value of education; youth and education; social exclusion; social sacred

Entre el mérito y la suerte: escuela, presente y futuro en la visión de estudiantes de primera enseñanza de Río de Janeiro

El artículo presenta resultados de una pesquisa denominada "Educación y exclusión social - lo sagrado bajo amenaza", que procura identificar factores que influenciarían en la formación de apreciaciones valorizadas más o menos favorables a la escuela. La hipótesis básica de la investigación propone la existencia de un esvaciamiento del significado del espacio escolar, para algunos sectores sociales largamente expuestos a un proceso de reducción de las oportunidades de movilidad social ascendente, por las trayectorias características de las sociedades modernas. Un breve re- 